\title{
Wildlife in Thailand
}

I $\mathrm{N}$ recent years both the water buffalo and the kouprey Novibos sauveli have been exterminated in Thailand, and the Thailand brow-antlered deer and hog deer are in danger, says Dr. Boonsong Lekagul, SecretaryGeneral of the Association for the Conservation of Wildlife in Thailand, in Conservation News, S.E. Asia. The dugong and the leathery turtle are also disappearing, and, although green and hawksbill turtles are hatched in nurseries and returned to the sea in large numbers, adult females caught by fishermen in their nets are still killed for their eggs. Losses of this kind are hard to assess. The numbers of elephants, gaur and banteng are decreasing rapidly, while all large birds, such as sarus crane, storks and pelicans, which make easy targets for the casual shooter, have seriously decreased. Night shooting from jeeps with spotlights is a serious factor and insecticides used by farmers are having their effect.

Deforestation, as in so many developing countries, is extremely serious despite a government project to declare "Reserved Forests", and the government adoption of a slogan: "The forests are the greatest wealth of the nation. Those who destroy the forests are the most dangerous enemies to the country," shown daily on television and broadcast. "It is the only active work of the government so far seen by the public," comments Dr. Boonsong, who considers the lack of supervision in the field, or rather forest, as the most serious factor. The Minister of Agriculture has ordered helicopters to combat illegal tree-felling, but the use of a helicopter for such work in dense forest, says Dr. Boonsong, is limited, and for the cost of one machine 800 landrovers could be bought, enough to supply one to every forester in the country.

One national park has been declared, on Khao Yai Mountain, 150 kilometres north of Bangkok, but unfortunately, Dr. Boonsong writes: "The committee concerned with this national park is mainly composed of diplomats, military and lay people who have not much interest in its true concept, and who seem to envision it as a hill station or health resort with rose gardens, playgrounds and sports fields rather than a national park in the true sense... this needs help from some international organisations." The Association for the Conservation of Wildlife of Thailand has a varied educational programme, with lectures, radio and television programmes, articles in newspapers, field trips and the compilation and free distribution to schools of two textbooks for a conservation course which has been introduced into Thai schools.

But the lack of experts and trained officers to work in both the national park and the wildlife services is the most hampering factor. Because the countries of South-east Asia have so much in common, in geography, climate, flora, fauna and ethnology, and even in political and financial problems, Dr. Boonsong suggests that a practicable and economical solution of this problem would be to establish an inter-Asian training school in one of these countries where the political situation is stable. This would be less expensive than sending men for training abroad, and the training would be given in the sort of country in which the trainee would later work. 